\title{
The Effects of Rolling Back State Frontiers on the Development of Nigeria's Economy (2003 - 2007)
}

\author{
Ndifreke S. Umo-Udo (Ph.D) \\ Department of Political Science and Public Administration, \\ University of Uyo, Uyo, Akwa - Ibom State, Nigeria
}

Doi:10.5901/mjss.2017.v8n2p259

\section{Abstract}

\begin{abstract}
The study focused on the deregulation of the downstream of Nigeria's petroleum sub-sector as an aspect of Rolling back the state in Nigeria. Deregulation of the downstream of the petroleum sector is occasioned by the removal of subsidies on petroleum products. This paper is adapted from my Ph.D research work at the University of Nigeria, Nsukka on rolling back the state. The objective was to examine the impact of deregulation of the downstream of the petroleum sector on the road transport sectors of the Nigerian economy within the period 2003-2007. Data for the study were generated through the observations of primary and secondary sources. The data were analysed using tables, percentage and correlation analysis. The findings of the study shows that deregulation of the downstream of the petroleum sector allowed the private sector owned road transportation system to increase the cost of transport fares anytime the government announced increase in the pump price of products. An increase in the cost of road fares translated into increase in prices of goods and services which ultimately resulted in inflation. Equally the huge amount derived from petroleum has not been judiciously expended for building and construction of roads. The research recommends that government should monitor the execution of road contracts to guard against none and poor delivery of jobs.
\end{abstract}

Keywords: Deregulation, Road Transport, downstream, petroleum, subsidy

\section{Introduction}

The welfare state and state intervention in the economy in the twentieth century was characterized by the promotion of the involvement of the state on behalf of the citizens to create the necessary conditions that will enable the individual to realize their full potentials in the society. Even in countries like Nigeria that are not welfare states, it is accepted that the state must be involved in welfare of the people. However, the end of the cold war led to the capitalist prescription of neoliberal policies and the operation of the free market economy which globally has led to rolling back the gains of the welfare state and divestment of the state from welfare matters. The background to this is the increasing process of globalization in the international economy, which has led to the pressure on national governments to reduce wage costs in order to attract high investment (Carpenter, 1996).

Rolling back the state frontiers are premised on measures such as privatization and other policies which the institutions of the Bretton Woods have compelled African countries to adopt to better their economies. The multi-lateral institutions have argued that the public sectors of the stricken African economies are over bloated to facilitate efficient growth, but have also been a drain of resources and public revenue (Timamy, 2007). This thinking runs contrary to the postulations of the British economist, J. M. Keynes whose model was tailored towards the pursuance of a policy of full employment through government intervention in the economy. Also, W. H. Beveridge, popularly refer to as the chief architect of the welfare state in Britain in his famous report of 1942 prescribed a framework for the provision of basic needs, and also remedies for problems in the society (Givertz, 1972). These services are generally termed as 'social safety net' a term used to describe a collection of welfare services provided by the state through unemployment benefits and sometimes subsidized services such as public transportation, healthcare and free education which can go a long way to enhance the wellbeing of members in the society

The rolling back of state involvement in welfare matters is viewed as attempts by the government to hands off partly or wholly from its traditional role or function of providing collective welfare to the people. The move toward rolling back the state is greatly underpinned on the advocacy of Milton Friedman and his Chicago School Movement. Friedman known as the architect of the movement for unrestrained capitalism and the man credited as the advocate for a contemporary, hyper mobile global economy. In one of his works, Friedman articulated contemporary capitalism's strategy, known as "shock doctrine". He observes that "only a crisis - actual or perceived produces change". When such 
crisis occurs, the actions that are taken depend on the situation on ground. For more than three decades, Friedman and his powerful followers have been ensuring this very strategy: waiting for a major crisis to occur then privatizing the state private concerns through reforms while citizens were still reeling from the shock then quickly making the "reforms" permanent (Klein, 2007).

In the current wave of liberal globalization and its attempt to liberalize, privatize and ensure a global economy, the concept of the welfare state and state involvement in welfare matters have been seriously been looked down upon in many parts of the world and indeed, Africa. To elaborate further, governments in Africa and Nigeria in particular no longer promote industrialization by deliberate policy measures rather incentives are focused on production of primary commodities. Nations are forced to give up the push for a more export oriented economy (Offiong, 2001).

Of recent, many government programmes and policies have been subjected to serious criticisms by the press and well placed Nigerians. Cases such as the attempt to deregulate the downstream of the petroleum sector, the privatization programme of the government, the contributory pension act scheme, the monetization of fringe benefits in the public service with its attendant consequence of right sizing and downsizing as well as efforts by the Obasanjo administration to decentralize the Nigerian Labour Congress are illustrative of this situation (Umofia, 2005). All these are the various efforts adopted to roll back state involvement in national economic activities in an era of economic globalization.

\section{Statement of Problem}

Under a package of International Monetary Fund (IMF) endorsed reforms, it is hoped that liberalised policies in the petroleum sub sector will lead to competition thus ensuring the growth of the Nigerian economy. The policy has led to the removal of domestic fuel subsidy, with the attendant increase in the pump prices of domestic petroleum products. This has brought untold hardship and the continuous pauperization of the citizens. Low prices of petroleum products which could have been one of the few economic benefits for the already impoverished Nigerians who see price increases as another attempt to enrich the pockets of the local oil marketers, importers and foreign oil companies. This has called into question the presumption that deregulation can necessarily lead to the reduction of poverty and enhance economic growth and development.

Although the federal government's plan to deregulate the petroleum sub sector began on $1^{\text {st }}$ January 2002, September 2003 marked the commencement of full liberalization which has led to increase and adjustments of the pump prices of petroleum products over the years. The government of President Olusegun Obasanjo gave reasons for accepting the full deregulation of the downstream of the petroleum sub sector. The decision as explained by the Obasanjo administration was in line with the recommendation of the presidential committee set up on the global economic crisis. The decision was taken because it has become clear that the huge amount of money being spent regularly by government on subsidy was actually "a case of subsidizing inefficiencies in the fuel supply and distribution network". Such monies expended on subsidy could be funneled into enhancing the critical sectors of the economy so that the overall benefit could be felt by all Nigerians, particularly the masses (Okereke, 2009).

Accordingly, this research shall be guided by the following research question:

(1) Was there any significant positive relationship between the deregulation of the downstream of the petroleum sector and the development of the road transport sector of the Nigerian economy?

\section{Objectives of the Study}

In carrying out this study, the broad objective of the study was to understand the effects of rolling back the state on the political economy of Nigeria. Its specific objectives were to:

(i) Examine the impact of deregulation of the downstream of the petroleum sector on the road transport sector within the period $2003-2007$;

(ii) Analyse the inevitable role of government to provide welfare, organize development and regulate the economy.

\section{Literature Review}

Nkoro (2005: 1) opines that deregulation has saddled the people with the burden of the continuous increase in the cost of fuel that is consumed locally. To him, leaving the pricing at the mercy of market forces has led to a situation that importers make abnormal profits at the expense of the country and its ordinary citizens. He maintains that the effect of price hike has led to the worsening of the economic crises which has affected the gross domestic product (GDP). 
Accordingly, this pattern of relationship can be attributed to labour unrest during fuel price hike which consequently affects the revenue that would have accrued to the coffers of government to be used in the provision of basic infrastructure in hospitals, good roads and education.

Describing the situation that led to the establishment of the Petroleum (Special) Trust Fund (PTF) by the Abacha government, Anam-Ndu (1998: 142) observes that following the new pricing of petroleum products introduced in 1994, the resultant gain was put into a special account for investment for the benefit of the Nigerian people. The PTF was established to manage the fund by timely execution of carefully designed socio-economic projects to enhance the general condition of living for all Nigerians in the shortest period possible. The fund was instrumental to the construction of roads, building of hospitals and supply of drugs to hospitals in various parts of the country. It is to be noted that even before the abolition of the fund by the Obasanjo administration, the fund was widely criticized on the issue of uneven spread in the execution of development projects across the country.

In the same vein, Arosanyin (2006:56) on assessment of Nigeria's transportation sector in the era of democracy, has pointed out that the chaotic transport sector of the economy is a pointer to disenchantment about democratic governance as seen in the numerous strike actions on the increments in the pump price of petroleum products particularly premium motor spirit P.M.S. for vehicles. Emeka Okafor in a critical overview of recent developments in the petroleum sub sector in Nigeria maintains that although Nigeria is the sixth largest producer and exporter of crude oil, this has not translated into a better living condition for the masses. To him, subsidies which government always insists must be removed has often led to strife and contention to the extent that whenever the pump price(s) is increased by government the labour union has often resorted to strikes which sometimes culminate into violent crises. This has cost the nation a great deal of setback in terms of the hours or days lost in various establishments as well as shutting down all sectors of the economy. There are often attendant losses of lives as a result of police brutality in the course of quelling the riots (Okafor, 2007: 92).

In the same vein, Ikein observes that although the oil revenue made it possible for the government to embark on massive road construction after independence, the building of roads was highly disproportionate; rural infrastructure lagged behind intercity and intra-city constructions. There was little or no attention given to road development in rural oil producing areas. He further maintains that rural roads constitute $44 \%$ of available roads in the country but receive minimal attention and maintenance, and during the rainy season, the roads are hardly passable. Many rural areas are still inaccessible by road, particularly in the riverine areas of the Niger Delta. The residents of these areas rely heavily on waterways, some of which are not navigable in the dry season. It is therefore difficult for the residents to transport goods and services to desired markets (Ikein, 1990: 82-84).

In his analysis of "Economic Liberalization, political Instability and State Capacity in Venezuela", Jonathan D. John maintains that double increase in the price of gasoline which was passed on by private bus companies onto the citizens, induced outbursts which led to its bloodiest urban riots. Though the government had actually announced that bus fares were allowed to rise by 30 percent, it did not monitor the increases bus companies were charging. Moreover, bus drivers ignored discounts to students. The riots which ensued were contained by a relatively undisciplined military response that left more than 350 people dead in two days (John, 2005: 114).

Adedipe (2004) in the analysis of "the impact of oil on Nigeria's economic policy formulation" is of the view that the incessant crisis in supply of petroleum products culminated in the decision by the government in 2003 to open up the downstream sub-sector. He however argues that, the manner of its implementation has been controversial because it ignores economic realities and the deplorable state of infrastructure such as inadequate electricity and power generation, bad roods, dilapidated schools and ill-equipped hospitals in Nigeria. He goes on to say that policies designed to address the deficiencies and defects in the polity end up being poorly articulated or implemented because of regional, political or rent-seeking selfish interest of those in authority. He maintains that, it is the same rent seekers that continually sabotage the re-invigoration of the domestic refineries, making Nigeria to depend on importation of refined products to meet domestic need.

\section{Theoretical Framework}

However, for the purpose of an in-depth analysis, the theoretical disposition adopted for this work was anchored on the social production theory which can be located in the Marxian methodology of dialectical materialism as espoused by Karl Marx and Frederick Engels. In order to grasp the Marxian methodology we must bring in the Marxian objective of study, which guided his choice of the relevant variables and their ordering in his scheme. Marx was basically interested in laying bare the laws of motion of the society. In other words, he wanted to find out the laws according to which the society moves from one historical category to another. The philosophy of Hegel had assigned the role of prime mover to ideas. 
According to this reasoning, there are always certain ideas, called theses. The theses have their antitheses or opposite ideas. A reaction takes place between these and antitheses and the result is syntheses or new ideas, which attract their own antitheses. Marx used a similar approach, but instead of assigning ideas to the role of prime movers, he came to rest on the material conditions of social life.

Bhatia (1981) in the analysis of the Marxian system maintains that social production necessitates the creation of corresponding social production relations and these relations take various forms. Their nature is not fixed, but changes with the degree of the development of the social productive forces. The economic structure of the society is nothing but a correspondence to these production or (social production) relations. These may be collectively called the mode of production. According to Marx, the mode of production in the society is responsible for the shaping of other aspect of life in the society such as the social, political, legal, religious and other processes of life. He posits further that the consciousness of men is not determined based on their existence but the other way round social existence determine the consciousness of men

Though one would have expected that the mode of production and the superstructure to be in harmony with each other, the social production relations imply the concomitant exchange and distribution patterns also. Since the production relations are based upon property relationships, therefore the exchange and distribution patterns also follow suit. Also when a new set of property relations come into being, a corresponding superstructure (which conforms to the new mode of production also comes into being). The very evolutionary process brings the mode of production and the superstructure into conflict with each other. A process is set into motion by which the existing mode of production will eventually be replaced by a new one and there will be a new superstructure in harmony with the mode of production.

The suitability of this theory for this work is best explained on the fact that the rolling back of the state and the adoption of deregulation and other economic reforms presupposes the benefit in the free market system. Its prototype is laissez-faire, anchored on the doctrine of Adams Smith's invisible hand" which is propagated by its promoters the World Bank and International Monetary Fund IMF, in the prescription of structural reforms to poor countries.

On the impact on transport sector the deregulation of the downstream of the petroleum sector allows the unregulated private sector owned road transportation system which helps in providing freight and passenger services to increase the cost of transport fares anytime an increase in the pump price of petroleum products is announced. An increase in the cost of transport fares translates into increase in the prices of goods and services which ultimately results in inflation.

\section{Hypothesis}

There exist a significant positive relationship between the deregulation of the downstream of the petroleum sector and the development of the road transport sector of the Nigerian economy.

\section{Presentation of Data}

Table 1: Percentage increase/decrease in PMS Price Adjustment 2003 - 2007

\begin{tabular}{|l|c|c|}
\hline Date/Year & Price (N/Litre) & Percentage Increase/ Decrease \\
\hline June 20, 2003 & From 26 to 40 & 53.7 \\
\hline July 9,2003 & From 40 to 34 & 17.5 \\
\hline October 1,2003 & From 34 to 42 & 17.5 \\
\hline May 29, 2004 & From 42 to 49.9 & 19 \\
\hline January, 2005 & From 49.9 to 50.5 & 1 \\
\hline August 26, 2005 & From 50.5 to 65 & 22.8 \\
\hline May 24, 2007 & From 65 to 75 & 15.4 \\
\hline June 23, 2007 & From 75 to 70 & 7.1 \\
\hline
\end{tabular}

Source: PPMC

The table above shows the percentage increase/decrease in PMS Price Adjustment between 2003 - 2007. It shows that fuel price was increase and adjusted for a record of eight times. 
Table 2: Percentage distribution of GDP of the road transport sub-sector, $2003-2007$

\begin{tabular}{|c|c|}
\hline Year & Percentage distribution \\
\hline 2003 & 1.68 \\
\hline 2004 & 2.38 \\
\hline 2005 & 2.38 \\
\hline 2006 & 2.40 \\
\hline 2007 & 2.42 \\
\hline
\end{tabular}

Source: NBS (Nigerian Statistical Fact Sheet, 2007:8)

The table above shows the analysis of the percentage distribution of the Gross Domestic Product (GDP) at constant basic prices in the Road Transport sub-sector indicates the following percentage distribution; $1.68 \%$ in 2003, 2.38\% in 2004, 2.38\% in 2005, 2.40\% in 2006, and 2.42\% in 2007 (NBS, Statistical Factsheet, 2007:8).

\section{Data Analysis}

Table 3: Correlation Analysis on Percentage Increase/Decrease in PMS Price Adjustment and GDP on Road Transport subsector between the period of study $2003-2007$

\begin{tabular}{|c|c|c|c|c|c|}
\hline Year & $\begin{array}{c}\text { \% increase/Decrease in PMS price } \\
\mathbf{X}\end{array}$ & $\begin{array}{c}\text { \% of GDP on Road transport subsector } \\
\mathbf{Y}\end{array}$ & $\mathbf{X Y}$ & $\mathbf{X}^{2}$ & $\mathbf{Y}^{2}$ \\
\hline 2003 & 29.57 & 1.68 & 49.68 & 874.38 & 2.82 \\
\hline 2004 & 19.00 & 2.38 & 45.22 & 361.00 & 5.66 \\
\hline 2005 & 11.90 & 2.38 & 28.32 & 141.61 & 5.66 \\
\hline 2006 & 0.00 & 2.40 & 0.00 & 0.00 & 5.76 \\
\hline 2007 & 11.25 & 2.42 & 27.23 & 126.56 & 5.86 \\
\hline & 71.72 & 11.26 & 150.45 & 1503.55 & 25.76 \\
\hline
\end{tabular}

Source: Author's computation

$\mathrm{H}_{0}$ : There exist no significant positive relationship in the deregulation of the downstream of the petroleum sector and the development of the road transport sector of the Nigerian economy.

$\mathbf{H}_{1}$ : There exist a significant positive relationship in the deregulation of the downstream of the petroleum sector and the development of the road transport sector of the Nigerian economy.

Level of significance $=0.05$

$$
\begin{aligned}
& \text { Test Statistics } \quad \mathrm{t}=\frac{\mathrm{r}}{\sqrt{\frac{1-\mathrm{r}^{2}}{\mathrm{n}-2}}} \\
& \text { Where } \mathrm{r}=\frac{\mathrm{n} \sum \mathrm{xy}-\left(\sum x\right)\left(\sum y\right)}{\sqrt{\mathrm{n} \sum \mathrm{x}^{2}-\left(\sum \mathrm{x}\right)^{2} \mid \mathrm{n} \sum \mathrm{y}^{2}-\left(\sum y\right)^{2}}}
\end{aligned}
$$

$\mathrm{n}=$ the number of paired observations $=5$

number of degrees of freedom $=n-2=5-2=3$

$$
\begin{aligned}
& \mathrm{t}-\text { table }=\mathrm{t}_{0.05}^{(\mathrm{n}-2)}=\mathrm{t}_{0.05}^{(3)}=2.35 \\
& \mathrm{r}=\frac{5(150.45)-(71.72)(11.26)}{\sqrt{\left[5(1503.55)-(71.71)^{2} \sqrt{5(25.76)-(11.26)^{2}}\right.}} \\
& =-0.8
\end{aligned}
$$$$
\mathrm{t}=\frac{-0.8}{\sqrt{\frac{1-(-0.8)^{2}}{3}}}=\frac{0.8}{\sqrt{\frac{1-0.64}{3}}}=-2.29
$$ 
Decision Rule: $\mathrm{H}_{0}$ is rejected if the positive value of the calculated $\mathrm{t}$ is greater than its table value at 0.05 level of significance, and accepted when otherwise.

Conclusion: Since the positive value of the calculated $t=2.29$ is less than the table value of $t=2.35 \mathrm{H}_{0}$ is accepted, hence there is no significant positive relationship.

\section{Discussions}

Prior to the period of the deregulation of the downstream of the petroleum sector, the condition of the roads and other infrastructure were in critical condition, thus necessitating government's intervention. In spite of the huge sum of money sunk into road construction, rehabilitation and reconstruction by the federal and state governments, most Nigerian roads are still in a deplorable situation. This position confirms the report of Adebayo, et al (2009) in a survey conducted by the Punch Newspapers on roads in the Federal Capital Territory, Abuja and many states in the country which showed that much still need to be done in the areas of monitoring, execution, sincerity and political will to have an effective road infrastructure. The survey went further to show that though Nigeria was among the few African countries that could boast of sufficient road network, it was grossly inefficient because of the state of dilapidation.

A release by the Ministry of Works, Housing and Urban Development also cited in the Punch Newspaper indicates that the Federal Government controlled about $34,000 \mathrm{kms}$ of roads in the country. Also a document by the Federal Roads Maintenance Agency revealed that the country's national road network was currently estimated at $194,200 \mathrm{~km}$ with an estimated asset value of $\mathrm{N4,567}$ billion out of which $34,120 \mathrm{kms}$ (amounting to 17.6 per cent) were federal roads with asset value of N1,261 billion. The local and rural roads covered 129,580kms (66.7 per cent). The document also revealed that in 2007 the quality structure of the federal road network indicated that 15 percent was in a very good condition, 20 percent in good or fair condition while about 30 percent and 35 percent were in poor and bad conditions respectively. It also showed that for a period of eight years, about N500 billion had been expended on the rehabilitation of about $3,500 \mathrm{kms}$ of $34,120 \mathrm{~km}$ of federal road network (Adebayo, et at, 2009). The Federal Road Maintenance Agency has been ill-equipped to handle most the deplorable situations on the Nigerian roads. Their work of maintaining the road has not gone beyond the filling and patching of potholes on the roads.

An on the spot assessment of major roads in each of the geopolitical zones in the country shows that in the Southwest, Lagos-Ibadan road which is a dual carriage way is in a relatively fair condition with parts of the roads adorned with pot-holes and portions that had peeled off which needs to be refilled and upgraded. In the North-West zone, the Kano Katsina road is a single road of $156 \mathrm{~km}$, it has many pot holes and large stretches have been damaged by erosion due to lack of gutters for drainage. In the South-East, most of the roads are in poor condition with pot holes, gullies and erosion affecting them. This is due to lack of maintenance, as many of them have not been rehabilitated for over 30 years. The Owerri - Onitsha, is in a very bad condition with gullies and ditches adorning the whole stretch of the road. As a result, the road is unsafe and the traffic flow is very slow. Thus a journey of $1 \frac{1}{2}$ hours in the $90.5 \mathrm{~km}$ road takes about 3 hours or more.

In the South - South, the Warri - Port Harcourt (East/West Road) has become unmotorable due to neglect and poor maintenance. A journey from Warri to Port Harcourt, which ordinarily should take two hours, now takes about four hours, due to the poor state of the road. In 2008 Julius Berger Plc, the construction company awarded the reconstruction and rehabilitation of the road, had to pull out due to incidence of kidnapping of its expatriates staff. The Calabar-Itu highway which was constructed more than 25 years ago is in dire need of reconstruction, rehabilitation and expansion. The more than $90 \mathrm{~km}$ length of road is full of pot-holes with failed portions along the Odukpani axis in Cross River State. In the North- East, the Maiduguri-Damaturu Road is in fair condition though some potholes adorn many parts of the road with peeled off portions which needs to be reconstructed. In the North-Central, the Abuja-Keffi Road is in a fair condition due to its reconstruction and expansion. While the Jos-Shendam, Pankshin-Shendam, Jos-Langtang with a stretch to Namu were in their worst conditions and begging for attention during the period of the study.

\section{Conclusion}

From the findings of the research, it can be observed that the reforms carried out by the Federal government in the petroleum sector through deregulation has not yielded positive effects in the road transport sector of the Nigerian economy. Suffice it to say that the condition of the road transportation sector in Nigeria still remains comatose with the roads still in a deplorable condition. Though the government has expended huge sums of money for construction and rehabilitation of roads, this has not yielded positive dividends.

Government must therefore ensure that road contracts are not necessarily given out to government officials for 
political patronage. Efforts must be made to ensure that road contracts are executed according to specifications in the contract which should also take into consideration the volume and weight of vehicles that ply such roads. At the same time government must also ensure that the due process is strictly adhered to in the award of road contracts to competent and deserving road construction companies.

The state of the roads has been a bane to passengers and commuters who travel in these roads. This is occasioned by the fact that road travelers may sometimes have to spend longer time to complete their journey due to the deplorable condition in the roads. Cost of travelling on bad routes could also be high as vehicle owners will charge more fares to be used in the maintenance of the vehicles. Sometimes passengers are stranded due to heavy duty vehicles and trucks which might fall at the bad spots which often time block the roads and make it impassable. Also, such occurrences such as road accidents and arm robbery attacks are a common phenomenon due to the bad roads and this has led to loss of several lives and properties.

\section{Recommendations}

Government must ensure that it monitors the execution and implementation of road contracts and also prosecute erring contractors for non delivery or poor delivery of jobs. The government should also be guided by volume of traffic and weight or tonnage of vehicles to ensure that the quality of roads built will stand the test of time.

The Federal Road Maintenance Agency must be properly equipped in order to realize the task of repairing and fixing the nation's highways. The FERMA must be adequately supervised to ensure transparency and accountability in the operational funds for high way maintenance it draws from petroleum products pricing after the abolishing of the toll gates.

Also the bad portions on the roads must be fixed immediately, they should not be allowed to deteriorate so as not to cause accidents and hold ups which can also be used by robbers and criminals to rob and disposes unsuspecting road users of their money and other personal effects.

\section{References}

Adebayo, S. Owuamanam, J. Odesola, T. Obe, E. Adepega, A. Makinde, F. Adeosun, F. and Utebor, S. (2009) "Nigerian Roads Still in a deplorable state - Survey". www.punchng.com. accessed on 02/10/2010.

Adedipe, B. (2004). "The Impact of Oil on Nigeria's Economic Policy Formulation" Text of a paper presented at the conference on Nigeria: Maximizing Pro-poor Growth: Regenerating the Socio-economic Database, organized by overseas Development Institute in Collaboration with the Nigeria economic Summit Group. 16 - 17 June.

Anam-Ndu, E.A. (1998). The Leadership Question in Nigeria: A Prescriptive Exploration. Lagos: Geo-ken Associates.

Arosanyin, G.T. (2006). "An Assessment of Nigeria's transport Sector" in Emmanuel Ojo (ed). Challenges of Sustainable Democracy in Nigeria. Ibadan: John Archers Publishers Ltd.

Bhatia, H.L. (1981). History of Economic Thought Third Rev. Ed. Delhi: Vikas Publishing House PVT Ltd.

Carpenter, M. (1996). "Welfare State" in lain Mclean (ed). Oxford Concise Dictionary of Politics. Oxford: Oxford University Press .

Givertz, H. K. (1972) "Welfare State" in Sills D. L. (ed) Encyclopedia of Social Sciences. New York : Cromwell Collier and Macmillan Inc.

Ikein, A.A. (1990). The Impact of Oil on a Developing Country: The Case of Nigeria. Ibadan: Evans Brothers (Nigeria Publishers) Limited.

John, J. D. (2005). "Economic Liberalization and State Capacity in Venezuela" International Political Science Review. Sage Publications Ltd.

Klein, Noami (2007). The Shock Doctrine: The Rise of Disaster Capitalism. London: Penguin Books Ltd.

Nkoro, E. (2005). "Increase in fuel Price: Analysis of its Effect on Nigeria Economy". http://searchwarp.com/swa20448.htm. accessed on $14 / 01 / 2007$.

Offiong, D. A. (2001). Globalisation: Post Neo-dependency and Poverty in Africa. Enugu: Fourth Dimension Publishers.

Okafor, Emeka E. (2007). "Rethinking African Development: A critical overview of recent Developments in petroleum sub-sector in Nigeria". Journal of Social Science. Vol. 15 No. 5.

Okereke, Chima (2009). "Report on projects and project management in Nigeria". PM World Today Vol. XI, Issue III http://www.pmworldtoday.net accessed on 15/03/2009.

Statistical Fact Sheet on Social and Economic Development (2007). Abuja: National Bureau of Statistics.

Timamy, M. H. K. (2007), The Political Economy of Technological Underdevelopment in Africa: Renaissance Prospects, Global Tyranny and Organized Spoliation. Lagos: Concept Publications.

Umofia, D. (2005). The Nigeria Public Servant: The Hope of the Nation. Port Harcourt: Ekantuk Printech Company. 
ISSN 2039-2117 (online)

ISSN 2039-9340 (print)
Mediterranean Journal of Social Sciences MCSER Publishing, Rome-Italy
Vol 8 No 2

March 2017 